\title{
Educational Development in the New Era: New Changes, New Discussions, and New Enlightenment
}

\author{
Tingting Liu* \\ The School of Marxism, Tiangong University, Tianjin 300387, China \\ *Corresponding author: Tingting Liu, alina233@126.com
}

\begin{abstract}
Since the 18th National Congress of the Communist Party of China (CPC), there are new requirements for the development of education in China. In view of this, the Party and the State have proposed new opinions on the development of education around the idea of developing education with people-centered approach. In the new era, adhering to the new exposition of education to guide the reform and development of China's education enlightens us to ensure the modernization of education, serve the major development direction of the country, and assume people's satisfaction as the yardstick.
\end{abstract}

Keywords: New era; Education development; Modernization

Publication date: October 2021; Online publication: October 29, 2021

\section{Reality: New changes}

The education in China has made achievements since the reform and opening-up, especially since the 18th National Congress of CPC. However, people's yearning for a better life is multidimensional. While great progress has been made in the development of education, there are still problems perplexing the broad masses.

\subsection{Higher expectations for education}

In the new era, the diversified and dynamic educational needs of the people are reflected in all aspects. Divided by stages, it does not only require the improvement of the quality of basic education and higher education, but also the emphasis on the development of early childhood education and vocational education. In terms of types, it does not only require the reform of traditional school education, but also the attention to the influence of family education. From the perspective of educational subjects, it does not only require the strengthening of the construction of teachers, but also put forward new requirements, such as the emphasis on salaries and treatment of teachers. In response to the high expectations of the people for education, it is necessary to promote the transformation of education from "emphasizing scale and quantity" to "improving quality and promoting fairness" through various measures of education reform. In order to comply to the people's desire for educational development, there is a need to solve the imbalance and insufficient educational development while assuming "quality improvement" as the goal, and better realize educational equity.

\subsection{Fluctuations in students' state of mind}

Schools are the main place for talent training. Although the economic and social development expands the 
function and mission of schools, the most fundamental task of schools is to cultivate talents for national development. In recent years, with the world shrinking into a "global village," all kinds of ideological and cultural exchanges as well as collisions have been magnified, making it difficult for students, a group with shallow social experience, to identify correct values in a complex ideological environment. Especially in the new era of science and technology as well as material enrichment, the ideological impact and material temptation faced by young students are more prominent compared to the past. They need to be guided to establish correct values, world outlook, and outlook on life with unified ideas. This requires schools to guide students to strengthen their ideals and beliefs with scientific theories and correct ideas at all stages of growth.

\subsection{Restricted all-round development}

The all-round development of individuals requires the society to create positive conditions for them. This does not only include the corresponding satisfaction of intellectual development, physical development, and material needs at the basic level, but also the enrichment of personal spiritual world at a higher level. Each individual has the right to be respected in social life as well as pursue and enjoy beauty while giving full play to their talents and creativity in social activities. In particular, the achievements in development provide a material guarantee for human development, which highlights the pursuit of spiritual level, the enjoyment needs, and development needs of other levels. For example, people expect the affirmation of their existence through labor and hope to underscore their value as workers. To carry forward the labor spirit and cultivate the consciousness of "labor is the most glorious and the greatest" depends on the joint efforts of the society and schools in providing trainings with all-round development as the ultimate goal.

\section{Practice: New discussions}

Based on practice and answering the questions of the times, with the clarification of new expectations for educational development and the problems faced in promoting this cause, it is important to consider solving the problem of insufficient and imbalance development of education as well as guide the long-term development of the cause of education with new viewpoints and ideas.

\subsection{Place education in a strategic position to give priority to development}

On the basis of fully recognizing the strong supporting role of education in the national development and social progress, China has made major deployments to give priority to the development of education, accelerate the modernization of education, and build an educational power. By integrating the educational "National Plan" and the "Party's Plan" into the great cause of socialism with Chinese characteristics, it fully highlights the status of education in the overall development of the national cause and provides a fundamental basis for promoting the priority development strategy of education in the new era. At the same time, it is also an inevitable choice to improve people's livelihood and serve people to lead a better life. On the one hand, it provides people with more educational opportunities and different educational choices at different stages. On the other hand, it solves the problem of insufficient educational development, narrow the educational gap among regions as well as between urban and rural areas, and further promote educational equity ${ }^{[1]}$.

\subsection{Assume building morality and cultivating people as the fundamental task of education}

Building morality and cultivating people is the fundamental task of education. Morality refers to students having good moral quality and ideological cultivation while pursuing a noble spiritual world as well as condensing strong spiritual strength and spiritual support for the great rejuvenation of the Chinese nation. 
Cultivating talents refers to the responsibility of the school as the main place for talent cultivation in unifying education and talent cultivation, emphasizing moral behaviors in education and teaching, as well as cultivating students who understand great morality, abide by public morality, and strict with private morality. Therefore, building morality and cultivating people as the fundamental task of education requires schools to focus not only on knowledge and skills, but also on ideological and moral education in the process of cultivating young people into talents. In the stage of implementing the fundamental task of building morality and cultivating people, it is necessary to include those with culture and moral education as the fundamental criterion to carry out all works. In the stage of evaluating results, the effectiveness of building morality and cultivating people is the fundamental standard to evaluate all the works of the school.

\subsection{Cultivate socialist builders and successors with all-round development of morality, intelligence, physique, beauty, and labor}

All along, the issue of "Who to train?" has been the key issue of the education in China. The all-round development of morality, intelligence, physique, beauty, and labor is an important indicator to measure social progress and national development. In particular, "labor" highlights its important role in people's allround development and the important position of labor education in schools ${ }^{[2]}$. "Labor" does not only refer to people's labor ability, but also to arming the mind with theoretical knowledge and guiding practice. Cultivating future socialist builders and successors with all-round development of morality, intelligence, physique, beauty, and labor ensures that human development closely follows the trend of the times as well as the general trend of the world's development, not only based on the present, but focused on the future while enriching themselves in terms of knowledge and skills, improving themselves in cultivating morality and sentiment, proving themselves by integrating into labor production practice, as well as realizing that social development is opposite to human development.

\section{Future: New enlightenment}

Education is the foundation of the centennial plan. How to give full play to the role of education in laying the foundation for national development? This needs to be based on the idea of people-centered development along with the constant inclusion of all kinds of talents in the process of promoting socialist modernization and strengthening the country.

\subsection{Education oriented to modernization}

The historical origin of the exposition of "education facing modernization" can be traced back to the beginning of the reform and opening-up, the notion of "walking out of a Chinese-style road to modernization," and the educational concept of "three orientations" [3]. Since the 18th National Congress of the CPC, on the basis of in-depth investigation of the new changes in development and demands of the people, China has creatively expanded the content of modernization and included the modernization of national governance system and governance capacity ${ }^{[4]}$. The report of the 19th National Congress of the CPC places priority over the construction of people's livelihood and social governance and calls for accelerating the process of educational modernization ${ }^{[1]}$. The ideas and policies of promoting the process of socialist modernization with educational modernization in each period are consistent while keeping pace with the times, reflecting the top-level deployment of taking into consideration of the reality and future in educational development. In order to develop education in the new era, it is important to focus in the direction of educational development, drive education to face modernization, as well as provide human resources and scientific support to build a socialist modern power. 


\subsection{Education that serves the major development direction of the country}

The basic role and long-term impact of education on national development require the adherence to demand orientation and problem orientation while making corresponding deployments and adjustments according to the phased objectives of the national development. At present, the national demand for scientific and technological support is more urgent than ever before. The gap in several key technologies and core technologies is restricting the overall scientific and technological level in China and is even posing a threat to the national security and people's life ${ }^{[5]}$. In the face of the major needs of scientific and technological innovation as well as the practical needs of protecting the core interests of the country, education should meet the difficulties and innovate according to the situation, cultivate high-tech talents and management talents, promote the dissemination and learning of scientific and technological knowledge among young people, as well as strive to lay a solid foundation for cultivating talents with a far-reaching impact on education and teaching. For example, cultivate talents who are familiar with the Chinese model and the national conditions of various countries.

\subsection{Education that takes people's satisfaction as the evaluation standard}

In the field of education, running education to the satisfaction of the people is also a process to enhance the people's sense of happiness, gain, and security. The report of the 19th National Congress of the Communist Party of China stressed the need to accelerate educational modernization and run education to the satisfaction of the people ${ }^{[1]}$. It reflects the evaluation standard of "the times and the people are the examiners, we are the respondents," which requires us to take people's satisfaction as the evaluation criterion and strive to meet the people's needs for higher-level education. However, people's satisfaction is not constant but diversified and dynamic. In the past, during the era when educational opportunities were scarce, running education to the satisfaction of the people was manifested as ensuring everyone had access to education and educational opportunities. With the development of the times, the popularization rate of education has increased rapidly. In order to run education to the satisfaction of the people in the new era, it is not only necessary to continuously improve the level and quality of education, but also narrow the differences in education.

\section{Disclosure statement}

The author declares that there is no conflict of interest.

\section{References}

[1] 2017, Decisive Victory in Building a Well-Off Society in an All-Round Way and Winning the Great Victory of Socialism with Chinese Characteristics in a New Era - A Report at the 19th Congress of the Communist Party of China. People's Daily, (1).

[2] 2018, Xi Jinping Emphasized at the National Education Conference that China Should Adhere to the Path of Socialist Education with Chinese Characteristics, Cultivate Socialist Builders and Successors Who Develop Moral, Intellectual, Physical, and Moral Forces in an All-Round Way. People's Daily, (1).

[3] Deng X, 1993, Selected Works of Deng Xiaoping (Volume III), People's Publishing House, Beijing, 35.

[4] 2012, Unswervingly Follow the Road of Socialism with Chinese Characteristics and Strive to Build a Well-Off Society in an All-Round Way - Report at the 18th National Congress of the Communist Party of China. People's Daily, (1). 
[5] Xi J, 2019, In-depth Study of Xi Jinping's Important Exposition on Education, People's Publishing House, Beijing. 